\title{
Ultrastructural and Chemical Studies on Wall-deficient Forms, Spheroplasts and Membrane Vesicles from Mycobacterium aurum
}

\author{
By NALIN RASTOGI AND HUGO L. DAVID* \\ Service de la Tuberculose et des Mycobactéries, Institut Pasteur, 25 Rue du Dr Roux, \\ 75015 Paris, France
}

(Received 28 July 1980; revised 15 December 1980)

\begin{abstract}
Wall-deficient forms of Mycobacterium aurum were prepared by agitating the cells during exponential growth with D-cycloserine, glycine, lysozyme, EDTA and $\mathrm{LiCl}$ for approximately the time of three cell divisions $(18 \mathrm{~h})$. Wall-deficient forms were then converted to spheroplasts by gentle stirring with lysozyme and EDTA in a Tris/ $\mathrm{HCl}$ buffer containing sucrose until all the cells appeared spherical by phase contrast microscopy. Subsequent lysis by nucleases followed by osmotic shock produced membrane vesicles. Ultrastructural and chemical properties of the spheroplasts and membrane vesicles are described. The spheroplasts were susceptible to lysis by $0.25 \%(\mathrm{w} / \mathrm{v})$ sodium dodecyl sulphate and were permeable to certain enzyme substrates.
\end{abstract}

\section{INTRODUCTION}

Bacteria can be converted into spheroplasts by the addition to the growth media of chemical substances which either degrade the bacterial wall (e.g. hydrolytic enzymes) or interfere with its biosynthesis (e.g. certain antibiotics, glycine and D-serine etc.). Millman (1958) reported protoplast formation in mycobacteria after massive adsorption of inactive bacteriophages. Hydrolytic enzymes were used to form spheroplasts of Mycobacterium tuberculosis by Thacore \& Willett (1963) and Willett \& Thacore (1967), and antibiotics by Dorozhkova \& Volk (1972). There have been reports of spheroplast formation in some fast-growing mycobacteria and $M$. bovis BCG grown in the presence of lysozyme and glycine (Sato et al., 1965; Adamek et al., 1969). Protoplasts of M. smegmatis have been prepared by growing lysozyme-sensitive mutants in a rich medium containing lysozyme and DLmethionine (Yabu \& Takahashi, 1977) but the technique is cumbersome. Formation of whole cell ghosts from $M$. phlei has been reported (Asano et al., 1973) but wall material was present which maintained the shape of the ghosts almost the same as that of intact rod-shaped cells. Recently, protoplasts and whole cell ghosts have been prepared by lysozyme and EDTA treatment of wall-deficient forms of $M$. smegmatis, produced in a synthetic medium containing D-cycloserine and horse serum (Rastogi \& Venkitasubramanian, 1979).

We have now developed a reliable technique for preparing wall-deficient forms of $M$. aurum. This technique makes use of an antibiotic (D-cycloserine), a hydrolytic enzyme (lysozyme), an amino acid (glycine), a chelating agent (EDTA) and an autolysis-stimulating agent $(\mathrm{LiCl})$. We here describe the technique and report chemical and ultrastructural studies of the spheroplasts.

\section{METHODS}

Organism and growth. Mycobacterium aurum strain $\mathrm{A}^{+}$(Lévy-Frébault \& David, 1979) was grown as a shake culture in nutrient broth medium $\left(8 \mathrm{~g} \mathrm{l}^{-1}\right.$; Difco) at $37^{\circ} \mathrm{C}$. Cells were harvested in the exponential phase of growth $\left(48 \mathrm{~h}\right.$ ) by centrifugation at $10000 \mathrm{~g}$ for $20 \mathrm{~min}$ at $4^{\circ} \mathrm{C}$. 
For the addition of exogenous substances to actively growing cells, bacteria were grown as shake cultures in $250 \mathrm{ml}$ flasks with side-arms. Antibiotics, amino acids, chelating agents or any other spheroplast-inducing substances were added as sterile solutions during the exponential phase. Growth was followed by turbidity measurements at $650 \mathrm{~nm}$ and was compared with controls with no additions. In plotting inhibition curves, the turbidity of the culture at the time of addition of any substance was arbitrarily considered as 100 .

Preparation of wall-deficient forms. Mycobacterium aurum was grown to the exponential phase $(48 \mathrm{~h})$ and the following substances were then added (sterilized by passing through a $0.45 \mu \mathrm{m}$ pore size filter): D-cycloserine $\left(60 \mu \mathrm{g} \mathrm{m}^{-1}\right)$, glycine $(1.4 \%, \mathrm{w} / \mathrm{v})$, lysozyme $\left(200 \mu \mathrm{g} \mathrm{ml}^{-1}\right)$, EDTA $\left(2 \mathrm{mg} \mathrm{ml}^{-1}\right)$ and $\mathrm{LiCl}\left(1 \mathrm{mg} \mathrm{m}^{-1}\right)$. Incubation with agitation at $37^{\circ} \mathrm{C}$ was continued for approximately the time needed for three cell divisions $(18 \mathrm{~h})$. Wall-deficient forms were centrifuged at $16000 \mathrm{~g}$ at $4{ }^{\circ} \mathrm{C}$ for $45 \mathrm{~min}$.

Preparation of spheroplasts. Wall-deficient forms were resuspended $(1 \mathrm{~g}$ wet wt per $80 \mathrm{ml}) \mathrm{in} 30 \mathrm{mM}-\mathrm{Tris} / \mathrm{HCl}$ buffer ( $\mathrm{pH} 8 \cdot 0)$ containing $20 \%(\mathrm{w} / \mathrm{v})$ sucrose. Potassium-EDTA $(10 \mathrm{~mm})$ and lysozyme $\left(0.5 \mathrm{mg} \mathrm{ml}^{-1}\right)$ were added and incubation with gentle stirring at $37^{\circ} \mathrm{C}$ was continued for 180 to $240 \mathrm{~min}$. This treatment caused a decrease in the turbidity of the bacterial suspension at $650 \mathrm{~nm}$ and an increase in viscosity. When observed by phase contrast microscopy, all the cells at this stage appeared spherical. Spheroplasts were collected by centrifuging at $16000 \mathrm{~g}$ at $4{ }^{\circ} \mathrm{C}$ for $45 \mathrm{~min}$.

Preparation of membrane vesicles. Spheroplasts were resuspended in the smallest possible volume of 100

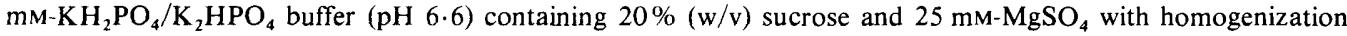
with a Vortex shaker or with a Teflon and glass homogenizer. DNAase I and RNAase A (Sigma; $7.5 \mathrm{mg} \mathrm{ml}^{-1}$ ) were added at this step and membrane vesicles were obtained by osmotic shock as reported previously for $M$. smegmatis (Rastogi \& Venkitasubramanian, 1979).

Preparation of mycobacterial wall and membrane controls by ultrasonic treatment. Bacteria harvested in the exponential phase of growth were washed twice with $50 \mathrm{~mm}-\mathrm{KH}_{2} \mathrm{PO}_{4} / \mathrm{K}_{2} \mathrm{HPO}_{4}$ buffer $(\mathrm{pH} 7 \cdot 6)$ and resuspended in the same buffer. Ultrasonic treatment was done at $20 \mathrm{kHz}$ with a $\mathrm{T}_{10}$ probe at $200 \mathrm{~W}$ (Universel, Type 20, 200 S; Société de Construction Mécanique, Aubagne, France) for $30 \mathrm{~min}$ in short bursts with rests to keep the temperature of the bacterial suspension around $4{ }^{\circ} \mathrm{C}$. Unbroken cells were removed by centrifuging at $5000 \mathrm{~g}$ for $5 \mathrm{~min}$. Wall and membrane fractions were obtained by centrifuging at $25000 \mathrm{~g}$ for $20 \mathrm{~min}$ and $46000 \mathrm{~g}$ for $45 \mathrm{~min}$, respectively.

Hydrolysis of cellular material for assay of amino sugars and diaminopimelic acid (DAP). The materials hydrolysed were intact cells, spheroplasts or membrane vesicles. Ultrasonically treated walls and membranes were used as controls. Cellular material $\left(1 \mathrm{ml}\right.$, approximately $\left.10 \mathrm{mg} \mathrm{ml}{ }^{-1}\right)$ was taken up in $\mathrm{KH}_{2} \mathrm{PO}_{4} / \mathrm{K}_{2} \mathrm{HPO}_{4}$ buffer $\left(50 \mathrm{mM}, \mathrm{pH} \mathrm{7.6)}\right.$ and dried in a glass ampoule at $105^{\circ} \mathrm{C}$ to determine dry weight. Then $1 \mathrm{ml} 1 \mathrm{M}-\mathrm{HCl}$ was added and the ampoule was sealed and heated at $110^{\circ} \mathrm{C}$ for $16 \mathrm{~h}$ for amino sugar hydrolysis. For DAP hydrolysis, the cellular material was hydrolysed with $1 \mathrm{ml} 6 \mathrm{M}-\mathrm{HCl}$ for $24 \mathrm{~h}$. In both cases, $\mathrm{HCl}$ was subsequently removed in vacuo over $\mathrm{CaCl}_{2}$. The residue was twice dissolved in water and re-evaporated to dryness. Hydrolysed material was dissolved in $1 \mathrm{ml}$ distilled water, and amino sugars were estimated by the Elson-Morgan reaction (Rondle \& Morgan, 1955) and the DAP was detected by thin-layer chromatography on cellulose (Staneck \& Roberts, 1974).

Phase contrast microscopy. All cellular preparations were mounted on thin layers of agar $\left(2 \mathrm{~g} \mathrm{l}^{-1}\right)$ to immobilize them for observation by phase contrast microscopy.

Ultrastructural studies. The cellular material was prefixed overnight in $2.5 \%(\mathrm{w} / \mathrm{v})$ glutaraldehyde (Sigma) solution in cacodylate buffer $(0.2 \mathrm{M}, \mathrm{pH} \mathrm{7.2)}$, washed repeatedly with the same buffer and postfixed overnight in $1 \%(\mathrm{w} / \mathrm{v}) \mathrm{OsO}_{4}$ in the same buffer. Bacteria at this stage were horizontally oriented as suggested by Whitehouse $e t$ al. (1977). Specimens in agar were dehydrated in a graded ethanol series and embedded in Epon 812 . Sections $(40 \mathrm{~nm})$ were cut with a LKB Ultrotome III using a diamond knife, mounted on copper grids, stained in uranyl acetate and lead citrate and observed in a Siemens 101 electron microscope.

Biochemical tests. The following biochemical tests, used frequently in the identification of mycobacteria, were performed: nitrate reductase (Vestal, 1975); Tween 80 hydrolysis (Kilburn et al., 1973); urease (Meyer \& David, 1979); arylsulphatase (Vestal, 1975); $\beta$-glucosidase (David \& Jahan, 1977); acid phosphatase (Kapler, 1965); and alkaline phosphatase (David, 1977).

Lytic action of sodium dodecyl sulphate $(S D S)$ on spheroplasts prepared from two different strains of $M$. aurum. Spheroplasts were prepared from $M$. aurum $\mathrm{A}^{+}$and its mutant $\mathrm{A}^{11}$ (Levy-Frébault \& David, 1979) and taken up in $5 \mathrm{ml} \mathrm{Tris} / \mathrm{HCl}$ buffer $(50 \mathrm{~mm}, \mathrm{pH} 8.0)$ containing $20 \%(\mathrm{w} / \mathrm{v})$ sucrose to give the same turbidity. Spheroplasts were then collected by centrifugation and resuspended in $5 \mathrm{ml} \mathrm{Tris/} \mathrm{HCl}$ buffer containing $0,5,10,15$ or $20 \%(\mathrm{w} / \mathrm{v})$ sucrose. SDS was added to give a concentration of $0.25 \%(\mathrm{w} / \mathrm{v})$ and the lytic effect was compared between spheroplasts and intact cells of the two strains. With intact cells, the SDS concentration was increased to $0.5 \%(\mathrm{w} / \mathrm{v})$ : no lysis was observed even after $24 \mathrm{~h}$ incubation at $37^{\circ} \mathrm{C}$.

\section{RESULTS}

Growth inhibitory effects on $M$. aurum of different substances. Mycobacterium aurum $\mathrm{A}^{+}$ was insensitive to penicillin but highly sensitive to isoniazid and D-cycloserine with minimal 


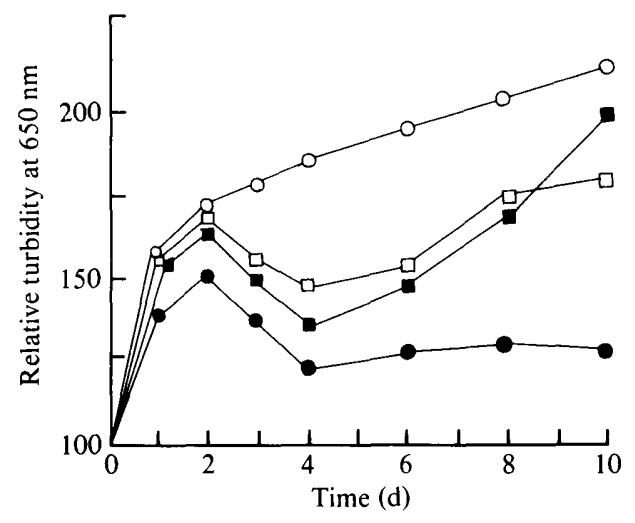

Fig. 1. Effect of addition of antibiotics to an $M$. aurum culture during the exponential phase of growth. The turbidity of the culture at the time of addition was considered as 100 . Additions: $O$, control (no addition);, $15 \mu \mathrm{g} \mathrm{D}$-cycloserine $\mathrm{ml}^{-1} ; \square, 0.2 \mu \mathrm{g}$ isoniazid $\mathrm{ml}^{-1} ; \mathbf{\square}, 15 \mu \mathrm{g} \mathrm{D}$-cycloserine $\mathrm{ml}^{-1}$ plus $0.2 \mu \mathrm{g}$ isoniazid $\mathrm{ml}^{-1}$.

inhibitory concentrations (m.i.c.) of 0.15 and $15 \mu \mathrm{g} \mathrm{m}^{-1}$, respectively. D-Cycloserine used alone was a more potent growth inhibitor than isoniazid used alone and addition of both isoniazid and D-cycloserine produced antagonism (Fig. 1). In another experiment, m.i.c. and $2 \times$ m.i.c. values of these antibiotics were used alone and in combination and the above observation was confirmed (results not shown).

The lytic effect of $60 \mu \mathrm{g}$ D-cycloserine $\mathrm{ml}^{-1}$ was tested in combination with $34 \mathrm{~mm}$ DL-methionine, $10 \mathrm{mM}$-D-serine or $1.4 \%(\mathrm{w} / \mathrm{v})$ glycine (Fig. 2). Its association with glycine produced maximal effect, causing 50 to $60 \%$ lysis of $M$. aurum cells. Various combinations of lysis-stimulating substances in association with $60 \mu \mathrm{g} \mathrm{D}$-cycloserine $\mathrm{ml}^{-1}$ and $1.4 \%(\mathrm{w} / \mathrm{v})$ glycine were tested on $\boldsymbol{M}$. aurum grown to exponential phase (Fig. 3). Lysis and formation of wall-deficient forms were observed by optical microscopy (some forms partially losing their acid-alcohol fastness, when stained by the Ziehl-Neelsen process) and by phase contrast microscopy (slightly swollen if suspended in $20 \%, \mathrm{w} / \mathrm{v}$, sucrose solution). A combination of $60 \mu \mathrm{g} \mathrm{D}$-cycloserine $\mathrm{ml}^{-1}, 1.4 \%(\mathrm{w} / \mathrm{v})$ glycine, $200 \mu \mathrm{g}$ lysozyme ml $\mathrm{m}^{-1}, 2 \mathrm{mg} \mathrm{EDTA} \mathrm{ml}^{-1}$ and $1 \mathrm{mg} \mathrm{LiCl} \mathrm{ml} \mathrm{m}^{-1}$ resulted in conversion of approximately $90 \%$ of the cells into wall-deficient forms, though apparent lysis, observed by the fall of turbidity at $650 \mathrm{~nm}$, was reduced from $60 \%$ in the case of $60 \mu \mathrm{g} \mathrm{D}$-cycloserine $\mathrm{ml}^{-1}$ and $1.4 \%(\mathrm{w} / \mathrm{v})$ glycine alone to approximately $35 \%$ (Fig. 3).

Morphological changes during lysis of bacterial forms. Intact bacteria were rod-shaped (Fig. $4 a$ ). When wall-deficient forms were treated with lysozyme and EDTA, a few spherical forms appeared after $60 \mathrm{~min}$ (Fig. $4 b$ ). After $180 \mathrm{~min}$, all the cells were spherical (Fig. $4 c$ ). Cells observed before lysis was complete showed all possible forms between spherical and rod-shaped structures.

Ultrastructural appearance. In Fig. $5(a)$, a distinct differentiation between the cell wall and the membrane can be seen for a rod-shaped bacterium. Conversion to spheroplasts (Fig. $5 b$, $c$ ) is represented by rounded forms in different stages of lysis and remnants of wall material still attached to the cytoplasmic membrane. Membrane vesicles are characterized by a complete lack of cytoplasmic material and cell wall, though in certain cases small fragments of residual wall might still be attached to the membrane (Fig. $5 d$ ).

Chemical evidence. Whole cells of $M$. aurum contained amino sugars and DAP, presumably derived from the bacterial wall since the membrane fraction prepared by. ultrasonic treatment of whole cells, used as a control in our experiment, contained no amino sugar and DAP was not detectable by thin-layer chromatography. The spheroplasts had less than half the amount of amino sugars and DAP (estimated by comparing the DAP spot 


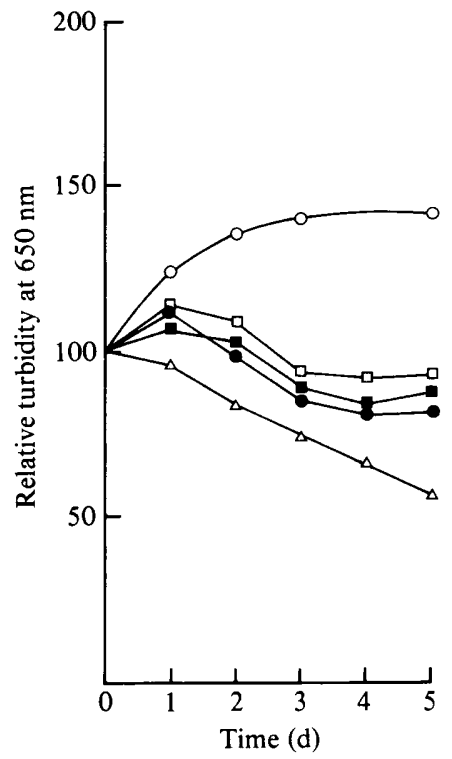

Fig. 2

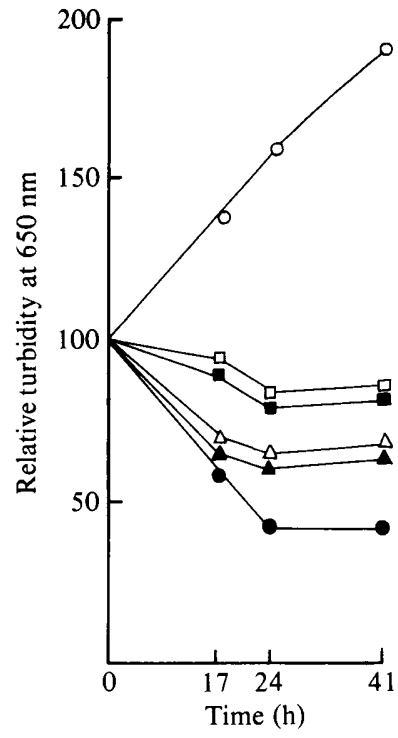

Fig. 3

Fig. 2. Lytic effect of $\mathrm{D}$-cycloserine in association with different amino acids, added to an $M$. aurum culture during the exponential phase of growth. The turbidity of the culture at the time of addition was considered as 100. Additions: $\bigcirc$, control (no addition);, $60 \mu \mathrm{g}$ D-cycloserine $\mathrm{ml}^{-1} ; \square, 60 \mu \mathrm{g}$ D-cycloserine $\mathrm{ml}^{-1}$ plus $34 \mathrm{mM}$-DL-methionine; $\square, 60 \mu \mathrm{g}$-cycloserine $\mathrm{ml}^{-1}$ plus $10 \mathrm{mM}$-D-serine; $\triangle$, $60 \mu \mathrm{g}$ D-cycloserine $\mathrm{ml}^{-1}$ plus $1.4 \%(\mathrm{w} / \mathrm{v})$ glycine.

Fig. 3. Effect of addition of substances stimulating spheroplast formation to an $M$. aurum culture at the beginning of the exponential phase of growth. The turbidity of the culture at the time of addition was considered as 100 . Additions: $O$, control (no addition); $0,60 \mu \mathrm{g} \mathrm{D}$-cycloserine $\mathrm{ml}^{-1}$ plus $1.4 \%(\mathrm{w} / \mathrm{v}$ ) glycine; $\square, 60 \mu \mathrm{g} \mathrm{D}$-cycloserine $\mathrm{ml}^{-1}$ plus $1.4 \%$ (w/v) glycine plus $100 \mu \mathrm{g}$ lysozyme $\mathrm{ml}^{-1} ; \mathbf{\square}, 60 \mu \mathrm{g}$ D-cycloserine $\mathrm{ml}^{-1}$ plus $1.4 \%(\mathrm{w} / \mathrm{v})$ glycine plus $200 \mu \mathrm{g}$ lysozyme $\mathrm{ml}^{-1} ; \Delta, 60 \mu \mathrm{g} \mathrm{D}$-cycloserine $\mathrm{ml}^{-1}$ plus $1.4 \%(\mathrm{w} / \mathrm{v})$ glycine plus $200 \mu \mathrm{g}$ lysozyme $\mathrm{ml}^{-1}$ plus $2 \mathrm{mg}^{\mathrm{EDTA}} \mathrm{ml}^{-1} ; \boldsymbol{\Delta}, 60 \mu \mathrm{g}$ D-cycloserine $\mathrm{ml}^{-1}$ plus $1.4 \%$ (w/v) glycine plus $200 \mu \mathrm{g}$ lysozyme $\mathrm{ml}^{-1}$ plus $2 \mathrm{mg} \mathrm{EDTA} \mathrm{ml}^{-1}$ plus $1 \mathrm{mg} \mathrm{LiCl} \mathrm{ml}{ }^{-1}$.

colour intensities on cellulose), while the membrane fraction prepared by osmotic shock had no significant amino sugars or DAP contamination.

Biochemical evidence. Out of seven biochemical tests performed, intact $M$. aurum cells were positive for nitrate reductase, Tween 80 hydrolysis and urease. The overall result was the same for $M$. aurum spheroplasts. However, urease $(2 \mathrm{~h})$ was positive for spheroplasts but negative for intact cells, whereas urease $(18 \mathrm{~h})$ was strongly positive $(+5)$ for spheroplasts and weakly positive $(+)$ for intact cells. Tween 80 hydrolysis $(1 \mathrm{~d})$ was positive for spheroplasts but negative for intact cells, whereas Tween 80 hydrolysis $(10 \mathrm{~d})$ was strongly positive $(+5)$ for spheroplasts and positive $(+2)$ for intact cells. This showed that our spheroplast preparations were more permeable than intact cells to certain enzyme substrates and that increased urea and Tween hydrolysis were due to more free penetration of substrates rather than to release of enzymes during the preparation of spheroplasts or during the tests themselves. The increase in colour intensity was a time-dependent phenomenon which clearly negates the possibility of release of enzymes during spheroplast preparation.

Spheroplast lysis by SDS. Figure 6 shows the lytic effect of SDS on spheroplasts prepared from $M$. aurum $\mathrm{A}^{+}$(wild-type) and its mutant $\mathrm{A}^{11}$, compared with intact $\mathrm{A}^{+}$and $\mathrm{A}^{11}$ cells. With $0.25 \%(\mathrm{w} / \mathrm{v})$ SDS, spheroplasts were lysed rapidly and after $1 \mathrm{~h}$ nearly $90 \%$ lysis had occurred, whereas even $0.5 \%(\mathrm{w} / \mathrm{v})$ SDS had no lytic effect on intact cells within $24 \mathrm{~h}$ of addition. 

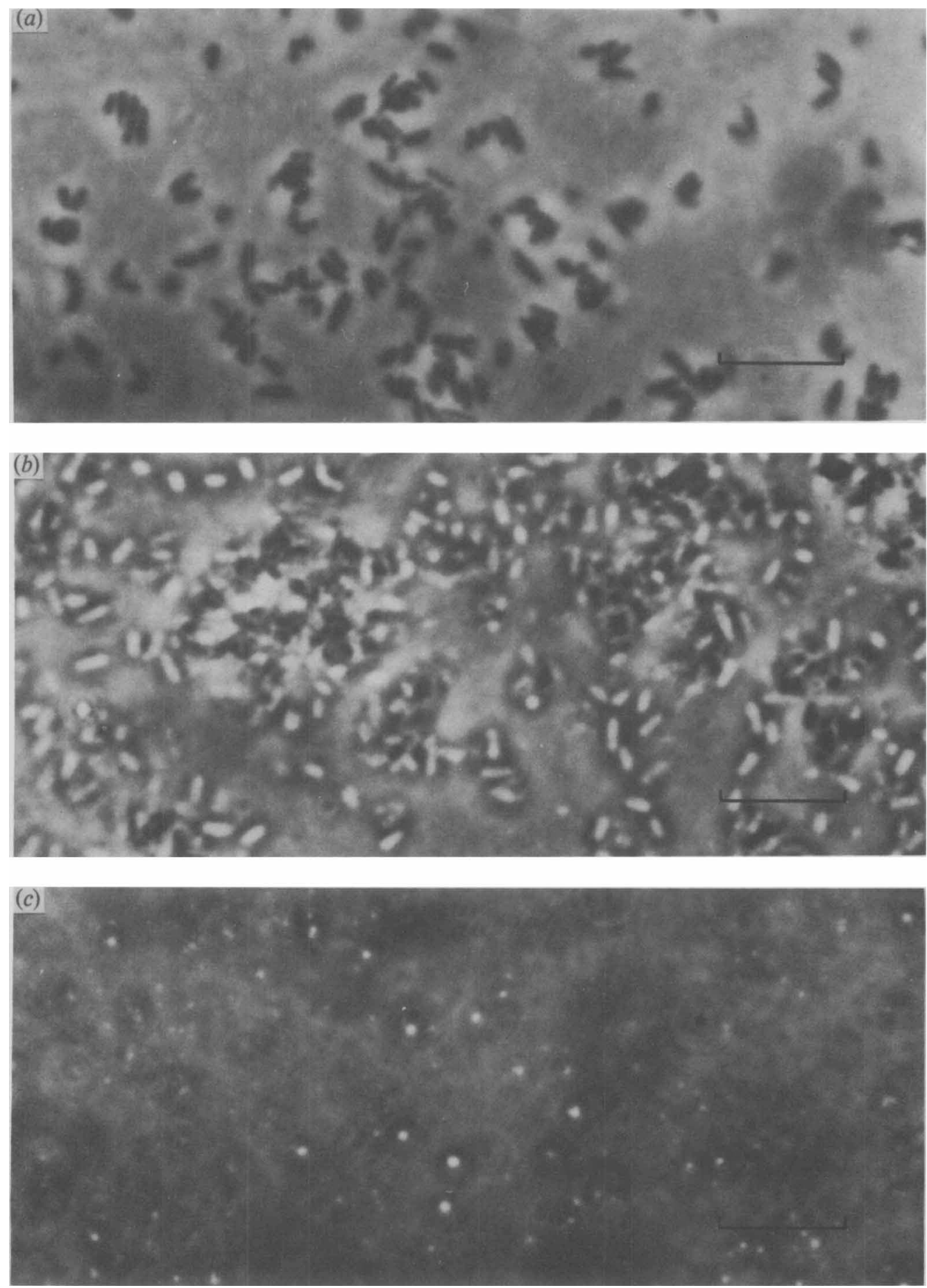

Fig. 4. Phase contrast micrographs of $M$. aurum during different stages of lysis. (a) Intact $M$. aurum $\mathrm{A}^{+}$cells were rod-shaped, 1 to $2 \mu \mathrm{m}$ in length and were stained dark red by the Ziehl-Neelsen process. (b) Wall-deficient forms after $60 \mathrm{~min}$ of lysis with lysozyme and EDTA (see text); a few spherical forms can be seen. (c) After $180 \mathrm{~min}$ of lysis, nearly all the bacteria were spherical. All the bar markers represent $10 \mu \mathrm{m}$. 


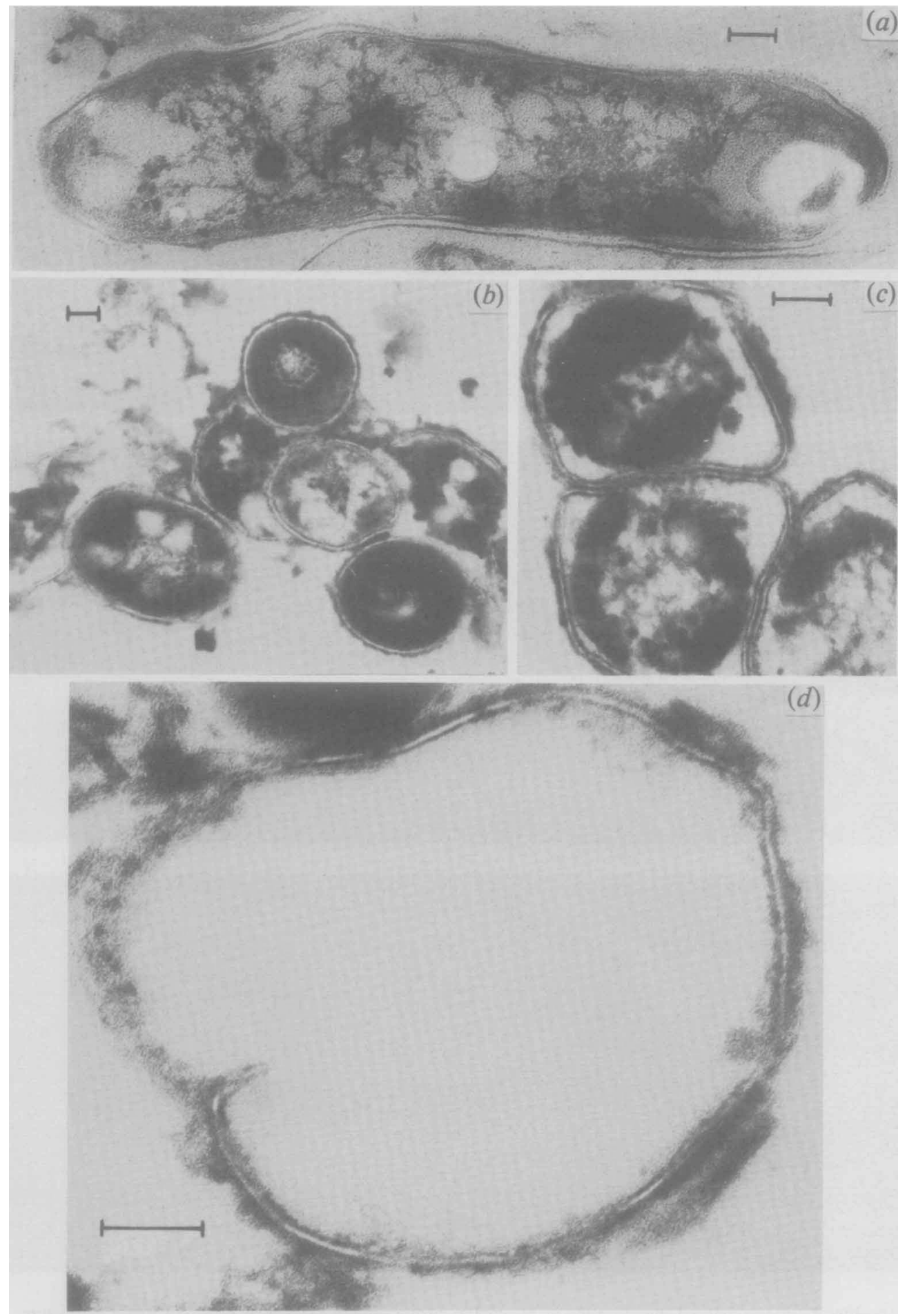

Fig. 5. (a) A rod-shaped $M$. aurum cell with a well-defined cell wall. $(b, c)$ Spheroplasts with forms at different stages of lysis, in some cases with a few remnants of wall material attached to the membrane. (d) Double-layered membrane vesicle, obtained by osmotic shock treatment. All the bar markers represent $100 \mathrm{~nm}$. 


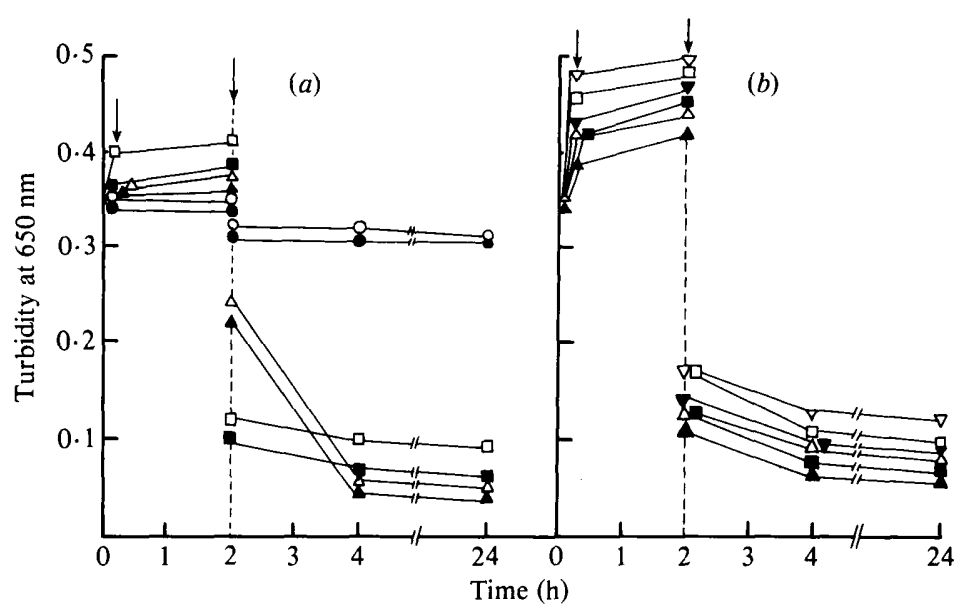

Fig. 6. Effect of addition of SDS to spheroplasts prepared from $M$. aurum strain $\mathrm{A}^{+}$(open symbols) and mutant $\mathrm{A}^{11}$ (closed symbols). Spheroplasts were diluted in sucrose solution at the time indicated by the first arrow, and SDS (final concentration: $0.25 \%, w / v$, for spheroplasts; $0.5 \%, w / v$, for intact cells) was added at the time indicated by the second arrow. (a) $\mathrm{O}, \boldsymbol{O}$, Intact cells; $\Delta, \Delta$, spheroplasts in $20 \%$ $(\mathrm{w} / \mathrm{v})$ sucrose; $\square, \mathbf{\square}$, spheroplasts in $15 \%(\mathrm{w} / \mathrm{v})$ sucrose. (b) $\triangle, \Delta$, spheroplasts in $10 \%(\mathrm{w} / \mathrm{v})$ sucrose; $\square, \mathbf{\square}$, spheroplasts in $5 \%(\mathrm{w} / \mathrm{v})$ sucrose; $\nabla, \nabla$, spheroplasts without sucrose.

\section{DISCUSSION}

Mycobacterium aurum was highly susceptible to the antibiotics isoniazid and Dcycloserine. Concentrations of nicotinamide nucleotides in mycobacteria decrease after exposure to isoniazid (Winder \& Collins, 1968) and exogenously added NAD has been reported to reverse the growth-inhibitory effect of isoniazid (Sriprakash \& Ramakrishnan, 1969). It has been proposed that isoniazid interferes primarily with NAD metabolism in mycobacteria (Krüger-Thiemer, 1958; Krishna Murti, 1975). Isoniazid also interferes with the synthesis of mycolic acid (Winder \& Collins, 1970). D-Cycloserine inhibits D-alanine racemase and D-alanyl-D-alanine synthetase, which are essential for the synthesis of UDP- $N$-acetylmuramoyl-tripeptidyl-D-alanyl-D-alanine, an intermediate in wall synthesis (Strominger et al., 1959; Neuhaus \& Lynch, 1964; David et al., 1969).

When used separately, both D-cycloserine and isoniazid stimulated cell lysis, but when used together, a certain antagonism was observed. In view of this observation we decided to use only D-cycloserine. To increase the lytic effect of D-cycloserine, we used growth-inhibitory amino acids. Glycine has been used previously in the case of mycobacteria (Sato et al., 1965, 1966; Adamek et al., 1969; Winder \& MacNaughton, 1978). Glycine is incorporated into the uridine nucleotide of Staphylococcus aureus in place of L-alanine, resulting in inhibition of growth (Strominger \& Birge, 1965). Incorporation of lower amounts of D-alanine and DAP has been reported in the bacterial wall in the presence of D-serine (Yabu \& Huempfner, 1974). DL-Methionine has been used previously in the case of $M$. smegmatis as it becomes incorporated into the bacterial cell wall in place of certain normal constituents (Lark et al., 1963).

Lysozyme acts on the innermost peptidoglycan layer of the wall, attacking the glycosidic bonds between $N$-acetylglucosamine and $N$-acetylmuramic acid (Strominger \& Ghuysen, 1967). EDTA is a chelating agent and might weaken essential glycosidic bonds, consequently making the peptidoglycan available for lysozyme action. It appears that $\mathrm{LiCl}$ is not directly responsible for lysis, but could stimulate autolysis by its effect on the cellular autolytic system (Kilburn \& Best, 1977). 
The action of lysozyme and EDTA on the bacteria could be followed due to changes in the shape of the bacteria, which presumably produce effects on their light scattering properties (Koch, 1961; Wyatt, 1973).

The true protoplasts released their intracellular contents after osmotic shock to form membrane vesicles, which could be sedimented at $45000 \mathrm{~g}$. In our preparations, slight contamination of membrane vesicles with wall residues could not be ruled out completely. Measurements on the photographs (Fig. 5d) suggest that this membrane is about 11 to $12 \mathrm{~nm}$ across, compared with approximately $9 \mathrm{~nm}$ reported by Imaeda et al. (1968). DNAase and RNAase were added during the ghost formation to hydrolyse intracellular DNA and RNA, which were otherwise released and became stuck to the exterior of the membrane.

In Fig. 6, the fact that the turbidity immediately became greater on dilution of the sucrose in a suspension of spheroplasts was probably due to the reduction of the refractive index of the medium in which spheroplasts were resuspended.

N.R. is grateful to the Government of France for a fellowship under a technical cooperation and exchange programme. We thank L. G. Chevance and H. Ohayon for considerable help in electron microscopy, J. Grzelak for phase contrast microscopy, and V. Lévy-Frébault for her valuable help in this work.

This investigation was supported by a grant from the Institut National de la Santé et de la Recherche Médicale (I.N.S.E.R.M.), France.

\section{RE FER E N C E S}

AdÁmek, L., Mišoň, P., MohelskÁ, H. \& TrNKa, L. (1969). Ultrastructural organization of spheroplasts induced in Mycobacterium sp. smegmatis by lysozyme or glycine. Archiv für Mikrobiologie 69, $227-236$.

Asano, A., Cohen, N. S., Baker, R. F. \& Brodie, A. F. (1973). Orientation of the cell membrane in ghosts and electron transport particles of $\mathrm{Myco}$ bacterium phlei. Journal of Biological Chemistry 248, 3386-3397.

David, H. L. (1977). Alkaline phosphatases from Mycobacterium smegmatis. Journal of General Microbiology 101, 99-102.

David, H. L. \& JAHAN, M.-T. (1977). R-Glucosidase activity in mycobacteria. Journal of Clinical Microbiology 5, 383-384.

David, H. L., Takayama, K. \& Goldman, D. S. (1969). Susceptibility of mycobacterial D-alanylD-alanine synthetase to D-cycloserine. American Review of Respiratory Disease 100, 579-581.

DorozhKova, I. R. \& VolK, A. V. (1972). Induction rate of L-forms in Mycobacterium tuberculosis under the effect of cycloserine and its combination with other drugs. Antibiotiki 17, 838-844.

Imaeda, T., Kanetsuna, F. \& Rieber, M. (1968). In-vitro effect of cycloserine on mycobacterial ultrastructure. Tubercle 49, 385-396.

KAPleR, W. (1965). Zur Differenzierung von Mycobacterien mit dem Phosphatase-Test. Beiträge zur Klinik und Erforschung der Tuberculose und der Lungenkrankheiten 130, 223-226.

Kilburn, J. O. \& Best, G. K. (1977). Characterization of autolysins from Mycobacterium smegmatis. Journal of Bacteriology 29, 750-755.

Kilburn, J. O., O’Donnell, K. F., Silcox, V. A. \& DAvid, H. L. (1973). Preparation of a stable mycobacterial Tween hydrolysis test substrate. Applied Microbiology 26, 826.

KoCH, A. L. (1961). Some calculations on the turbidity of mitochondria and bacteria. Biochimica et biophysica acta 51, 429-441.

KRISHNA MURTI, C. R. (1975). Isonicotinic acid hydrazide. In Antibiotics: Mechanism of Action of Antimicrobial and Antitumor Agents, vol. 3, pp. 623-652. Edited by J. W. Corcoran \& F. E. Hahn. New York: Springer-Verlag.

KRÜGER-THIEMER, E. (1958). Isonicotinic acid hypothesis of the antituberculous action of isoniazid. American Review of Tuberculosis and Pulmonary Diseases 77, 364-367.

LARK, C., Bradley, D. \& LARK, K. G. (1963). Further studies on the incorporation of D-methionine into the bacterial cell wall. Biochimica et biophysica acta 78, 278-288.

LÉvy-FrÉbault, V. \& DAVID, H. L. (1979). Mutations affecting pigment synthesis in Mycobacterium aurum. Journal of General Microbiology 115, 317-323.

Meyer, L. \& David, H. L. (1979). Evaluation de l'activité uréase et de l'activité $\beta$-glucosidase pour l'identification pratique des mycobactéries. Annales de Microbiologie 130B, 323-332.

Millman, I. (1958). Formation of protoplasts from mycobacteria by mycobacteriophage. Proceedings of the Society for Experimental Biology and Medicine 99, 216-219.

Neuhaus, F. C. \& Lynch, J. L. (1964). The enzymatic synthesis of D-alanyl-D-alanine. III. On the inhibition of D-alanyl-D-alanine synthetase by the antibiotic D-cycloserine. Biochemistry 3, 471-480.

Rastogi, N. \& Venkitasubramanian, T. A. (1979). Preparation of protoplasts and whole cell ghosts 
from Mycobacterium smegmatis. Journal of General Microbiology 115, 517-521.

RONDle, C. \& MORGAN, W. (1955). The determination of glucosamine and galactosamine. Biochemical Journal 61, 586-589.

Sato, H., Diena, B. B. \& Greenberg, L. (1965). The production of spheroplasts by rapid growing, nonvirulent mycobacteria. Canadian Journal of Microbiology 11, 807-810.

Sato, H., Diena, B. B. \& Greenberg, L. (1966). Spheroplast induction and lysis of BCG strains by glycine and lysozyme. Canadian Journal of Microbiology 12, 255-261.

SRIPRAKash, K. S. \& Ramakrishnan, T. (1969), Isoniazid and nicotinamide adenine dinucleotide synthesis in $M$. tuberculosis. Indian Journal of Biochemistry 6, 49-50.

Staneck, J. L. \& Roberts, G. D. (1974). Simplified approach to identification of aerobic actinomycetes by thin-layer chromatography. Applied Microbiology 28, 226-231.

Strominger, J. L. \& Birge, C. H. (1965). Nucleotide accumulation induced in Staphylococcus aureus by glycine. Journal of Bacteriology 89, 1124-1127.

STrominger, J. L. \& GHUYSEN, J. M. (1967). Mechanism of enzymatic bacteriolysis. Science 156, 213-221.

Strominger, J. L., Threnn, R. H. \& Scott, S. S. (1959). Oxamycin, a competitive antagonist of the incorporation of $\mathrm{D}$-alanine into a uridine nucleotide in Staphylococcus aureus. Journal of the American Chemical Society 81, 3803-3804.

ThacoRe, H. \& WilletT, H. P. (1963). Formation of spheroplasts of Mycobacterium tuberculosis by lysozyme treatment. Proceedings of the Society for Experimental Biology and Medicine 114, 43-47.

Vestal, A. (1975). Procedures for the Isolation and Identification of Mycobacteria. DHEW publication no. (CDC) 76-8230. Atlanta, Georgia: Center for Disease Control.

Whitehouse, R. L. S., Benichou, J. C. \& Ryter, A. (1977). Procedure for the longitudinal orientation of rod shaped bacteria and the production of a high cell density of procaryotic and eucaryotic cells in thin sections for electron microscopy. Biologie cellulaire 30, 155-158.

Willett, H. P. \& THACORE, H. (1967). Formation of spheroplasts of Mycobacterium tuberculosis by lysozyme in combination with certain enzymes of rabbit peritoneal monocytes. Canadian Journal of Microbiology 13, 481-488.

Winder, F. G. \& Collins, P. B. (1968). The effect of isoniazid on nicotinamide nucleotide levels in $\mathrm{Myco}$ bacterium bovis strain BCG. American Review of Respiratory Disease 97, 719-720.

WiNDER, F. G. \& Collins, P. B. (1970). Inhibition by isoniazid of synthesis of mycolic acids in $\mathrm{Myco}$ bacterium tuberculosis. Journal of General Microbiology 63, 41-48.

Winder, F. G. \& MacNaughton, A. W. (1978). A relatively rapid procedure for the preparation of lysis-susceptible forms of Mycobacterium smegmatis. Journal of General Microbiology 109 , $177-180$.

WYATT, P. J. (1973). Differential light scattering techniques for microbiology. Methods in Microbiology 8, 183-263.

YABU, K. \& HUEMPFNER, H. R. (1974). Inhibition of growth of Mycobacterium smegmatis and of cell wall synthesis by D-serine. Antimicrobial Agents and Chemotherapy 6, 1-10.

YABU, K. \& TAKAHASHI, S. (1977). Protoplast formation of selected Mycobacterium smegmatis mutants by lysozyme in combination with methionine. Journal of Bacteriology 129, 1628-1631. 